\title{
The Influence of Sensory Gardens on the Behaviour of Children with Special Educational Needs
}

\author{
Hazreena Hussein \\ Department of Architecture, Faculty of Built Environment, \\ University of Malaya, Kuala Lumpur, Malaysia \\ reenalambina@um.edu.my
}

\begin{abstract}
This study explores the use of sensory gardens by observing the zones and how they are utilised by children with special educational needs. Methods applied were interviews, observation and behaviour mapping, which was used in conjunction with the affordance theory. Affordance was categorised by landscape furniture, soft and hard landscape in relation to three categories of activities: Sensory stimulation, physical and social skills. The findings had discovered continuous pathways that link the sensory garden to the site context, had easy access to the features, and had the highest number of user. This study also found that users spent a longer time in zones where sensory, rather than aesthetic value, was emphasised.
\end{abstract}

Keywords: Accessibility, affordance, behaviour, sensory

eISSN 2514-751X @ 2017 The Authors. Published for AMER ABRA by e-International Publishing House, Ltd., UK.. This is an open access article under the CC BY-NC-ND license (http://creativecommons.org/licenses/by-ncnd/4.0/). Peer-review under responsibility of AMER (Association of Malaysian Environment-Behaviour Researchers), ABRA (Association of Behavioural Researchers on Asians) and cE-Bs (Centre for EnvironmentBehaviour Studies), Faculty of Architecture, Planning \& Surveying, Universiti Teknologi MARA, Malaysia.

https://doi.org/10.21834/aje-bs.v2i4.214 


\subsection{Introduction}

\subsection{What is a sensory garden?}

A sensory garden is a 'self-contained area that concentrates on a wide range of sensory experiences. Such an area, if designed well, will provide a valuable resource for a wide range of users, ranging from education to recreation' (Sensory Trust, 2009). Shoemaker (2002:195) stated that a 'sensory garden cannot be designed without the consideration of the human element. Unlike traditional display gardens that are meant to be observed from a distance, sensory gardens draw the visitor into touch, smell and one can actively experience the garden with all senses'. What differentiates a sensory garden from any other gardens? 'The only difference is that in a sensory garden, all these components, (hard and soft landscaping, colours, textures and wildlife), must be carefully chosen and designed to appeal to the senses in such a way that they provide maximum sensory stimulation.' (Lambe, 1995:114)

\subsection{Historical background of sensory gardens}

In an interview that the researcher conducted with Jane Stoneham (August 9th 2006), the director of the Sensory Trust and the author of the book, 'Landscape Design for Elderly and Disabled People', Stoneham stated that the initial idea of sensory gardens was derived from the horticultural therapy movement, which was developed in the United Kingdom in the 1970s. Horticultural therapy was focusing on special environments, i.e. hospitals and rehabilitation units and, thus, causing it to be developed more rapidly than sensory gardens. One positive aspect of sensory gardens was the genuine response to meet the needs of the visually-impaired people. Stoneham also added that however, not much thought was given to the design of these gardens. The first sensory gardens were often located in public parks because the local authority decided that it was a way of showing that they were implementing inclusion strategies. However, the reality was that they were small areas, often signposted as 'Garden for the Blind', and they consisted of a combination of scented plants, Braille labels and raised planters. Over time, society's attitude towards disability changed, as did the function and users of the sensory garden. Any design for disabled people should be aimed to help overcome the stigma that is attached to being labelled as 'disabled'. Since the mid-1970s, society has suggested that this can be achieved more easily by integrating, rather than segregating facilities. In 1978, the then United Kingdom Minister for the Disabled, Alfred Morris said, 'The simplest way of causing a riot in any locality in Britain would be to clamp on the able-bodied the same restrictions that now apply to the disabled. They feel that their personal handicaps are bad enough without the gratuitous social handicap of being treated differently from everyone else' (Rowson, 1985:21). Stoneham (2006) added that in the 1980s, visually-impaired people challenged the initial ideas about 'gardens for the blind' because the issue of being segregated from able-bodied people was itself beginning to be challenged. It is now understood that disabled 
people do not want to be segregated from the able-bodied people in their enjoyment of green areas. The idea is to integrate green areas that allow an enhanced sensory experience, which will make for an inclusive approach rather than making 'special' provision for disabled people (O'Connell and Spurgeon, 1996).

\subsection{Literature Review}

\subsection{What are 'special educational needs'?}

The term 'special educational needs' covers an array of difficulties as highlighted in the 2001 Special Educational Needs Code of Practice, which 'recognises a wide spectrum of special educational needs that are frequently interrelated, although there are also specific needs that usually relate directly to particular types of impairment' (Department for Education and Skills, 2001:85, para.7.52). The Pupil Level Annual Schools Census data was amended in 2004 to include 12 categories of special educational needs: Specific learning disability, moderate learning disability, severe learning disability, profound and multiple learning disability, emotional and behavioural difficulty, speech, language and communication needs, hearing-impaired, visual impairment, multi-sensory impairment, physical difficulty, autism spectrum disorder and others. Most of the sensory gardens visited during the preliminary site studies (from which in this paper, one of two that was selected as case study is the Lyndale Special School in Liverpool, United Kingdom), provided access to children with at least one or more special educational needs, as per 12 categories listed above. In this study, the term 'special educational needs' will be used when describing the students using the case study sensory garden

\subsection{What is a multi-sensory environment'?}

A multi-sensory environment is a 'dedicated space or room... where stimulation can be controlled, manipulated, intensified, reduced, presented in isolation or combination, packaged for active or passive interaction and temporally matched to fit the perceived motivation, interests, leisure, relaxation, therapeutic and /or educational needs of the user' (Pagliano, 1998:107). Pagliano (1999:14) added, 'the multi-sensory environment literature can be divided into four themes, each describing a particular type of multi-sensory environment. The first multi-sensory environment closely follows the original 'Snoezelen Philosophy'1, which was created for leisure and recreation in favour of disabled people. The second theme has been developed principally for therapy, and specifically designed for the treatment of some disorder or condition. The third theme has been principally created for education to promote learning and development. The fourth theme is multi- functional, in which space can be used for leisure and recreation, for therapy, education or any combination of the three. Since the researcher selected school-based sensory gardens, this study utilises the third theme, that of a multi-sensory environment which is created for

'Snoezelen' is a contraction of two Dutch words, meaning to smell and to doze (Pagliano, 1999:8) 
educational use. In this study, the term 'multi-sensory' describes the multiple bodily senses, particularly to which students with special educational needs can be exposed, namely, to a stimulating environment that is designed to offer sensory stimulation using textures, colours, scents, sounds, etc. This type of environment provides an area for users to control, manipulate, intensify or reduce stimulation within a safe environment (Best, 1992) while relaxing, interacting and learning from one another (Glenn et al., 1996).

\section{Outdoor education}

Having an accessible school ground, is highly important to children, to give them the opportunity for free play and choices for exploring and learning. Titman (1994:58) identified four elements that children looked for in school grounds: A place for doing (opportunities for physical activities); a place for thinking (opportunities for intellectual stimulation), a place for feeling (to provoke a sense of belonging) and a place for being (to allow them to be themselves). Her research focused on the value of improved school grounds as an educational resource to demonstrate how students' attitudes, behaviours and learning skills could be enriched. One of the ways in achieving an environmental education is to choose plants that can grow rapidly can provide shade, can offer visual stimulation through their colourful, textured and scented characteristics. Plant compositions must be carefully considered so that they can provide mystery, have the ability to hide and to create space. One example of a school which has built this kind of environment is the Meldreth Manor School in Hertfordshire (Frank, 1996; Stoneham, 1996). The sensory garden there is designed with a series of ramps and raised integrated pathways and woven around the existing apple trees that offer pupils a variety of sensory experiences.

\subsection{Educational benefits}

Having a multi-sensory environment in special schools is beneficial for both teachers and pupils as it provides a two-way learning process. Building Bulletin 77 (1992:49) outlined, 'External spaces can provide opportunities for observation, investigation and problemsolving and this forms a flexible facility often more readily adaptable to change in user requirements than the building itself. They can offer a stimulating environment suited to practical activities from which many pupils with special needs can benefit'. This idea matches Titman's (1994), Lucas's (1996), Stoneham's (1997) and Moore's (1999) beliefs that outdoor environmental learning can give children a stimulating experience as well as influence their behaviour and their development in terms of social relationships. This notion has received further support from Barbara Dunne of the Royal School for the Deaf and Communication Disorders, Manchester: 'Pupils are most likely to succeed when they are involved in 'doing' activities rather than academic learning. Environmental education is an ideal learning medium and activity. (Stoneham, 1996:8). The research findings of Rohde and Kendle (1994), Malone and Tranter (2003) and

Maller and Townsend (2005/2006) have proven that providing school grounds with sensory stimulation can encourage mental development, health improvements, emotional growth 
and social integration, in addition to increasing the learning motivation of the pupil, especially when being in contact with animals and plants. For children with autism, they may 81 'seek sensory stimulation from the environment in order to calm or self- regulate their nervous system' (Stadele and Malaney, 2001:213). Research conducted by Learning through Landscape also confirmed that teachers appreciate outdoor areas as a foundation for the education of children with special educational needs and with whom they can assist in reducing aggressive behaviour and bullying.

\subsection{Disability}

Mount and Cavet (1995) and Chawla and Heft (2002) mentioned the richness of the visual, auditory and tactile stimuli that gardens could offer and the opportunities for exploration and thus, how they could assist users to develop an understanding of the environment. However, any impairment, disability or handicap would limit a person's ability to engage with the environment. The principal of Farrer Huxley Associates, Noel Farrer (2008:17) mentioned that, 'When designing for children with disabilities, it is vital to understand that their senses are completely different. You are not dealing with the same sort of physicality, you are dealing with texture, smell and sound; motor skills are far more localised... McLinden and McCall (2002:54) differentiated between the close senses (touch and taste), and the distance senses (sight, smell and hearing). They noted that 'when the distance sense of vision is impaired, young children may be able to compensate to some extent by making greater use of their other distance sense - hearing'. Best (1992:119), quoted by McLinden and McCall (2002:99), stated that 'when facial expression and tone of voice are too sophisticated (through learning difficulties) or inaccessible (through sensory impairments), then touch is the primary channel of communication for the children. Information and emotions will be conveyed through touch and so the adult will need to ensure that the intended message is being conveyed'. This is evident from the findings at the case-study site that the sense of touch has the highest sensory stimulation compared to other senses amongst the users of sensory garden.

\subsection{The concept of affordances}

'A key to understanding the implications of the built environment and children's active living is the concept of affordance.' (Gibson and Pick, 2000, quoted in Cosco, 2007:127) It helps us to understand the impact of the physical environment on children and to identify environmental attributes that are associated with specific behavioural responses.' (Gibson and Pick,2000, quoted in Cosco, 2006:17) The approach can be understood through three concepts: Affordance, information and pickup information (Gibson and Pick, 2000).

Affordance: Is defined as the functionally significant properties of physical opportunities and dangers, in which an organism perceives while acting in a specific setting (Gibson, 1979/1986; Gibson and Pick, 2000; Heft, 2001; Kytta, 2003). In other words, the 
environment features as a property of the relationship between the environment and the users and the possibilities that a place can offer users, whether or not the landscape architects intended those possibilities. Thus the concept of affordance, in Gibson's ecological approach, has been applied to 'examine the relationship between the functional properties of the environment and how environments are used' (Clark and Uzzel, 2002:95).

Information: The environment provides information as ambient arrays of energy that is structured by surfaces, boundaries, events, objects and layout of the environment (Gibson and Pick, 2000). The information perceived changes depending on the perceiver's movement (sitting, standing, walking, etc.) and their senses (sight, hearing, taste, touch and smell). These changes are essential for identifying, extracting and describing information about where one is, where one is going and what one is accomplishing. For example, users passing through the sensory garden often stop for a while to engage with the features that are adjacent to the pathway. Their engagement enables them to experience different views of the garden.

Pickup information: Is classified into two types: Exploratory and performatory (Gibson and Pick, 2000). The former permits children to discover the new properties of the environment and also about their own capabilities, while the latter is the outcome of already learned affordances and this relates to actions directed towards objects or an individual(s) within a setting for an intended purpose, for example, throwing, hitting, etc. 'Perception and action are closely intertwined in both exploration and performance, and learning is an important outcome of both types of action' (Gibson and Pick, 2000:21).

\subsection{Affordances in the design of sensory gardens}

The affordance theory raises questions that deserve exploration when the design of sensory gardens is being considered.

1. How familiar are users with the environment and are they encouraged enough to interact with the features in the alternative ways? For instance, a water feature stimulates the sense of hearing but the feature also offers an opportunity to splash water around.

2. What do users of sensory gardens usually do in terms of affordances? For example, rather than focusing on the footpath, bench or grassy area, it may be more beneficial to observe the frequency of activities such as running, leaning, crawling in this particular setting. In addition, it will be more fruitful to consider the accessibility of these observed affordances, i.e. the potential for users' physical engagement with the environment, whether the physical activity is accessible or is not being actualised because of the barriers.

3. How do these features offer users the chance to evaluate their benefits or disadvantages? Are the affordances in the sensory garden accessible? If not, why not? How have these affordances been actualised? 
In this study, the concept of affordances is useful in describing the engagement between the users and the garden features, the users' responses as well as the possibilities that a sensory garden can offer its users and whether or not landscape architects have intended those possibilities when designing sensory gardens.

\subsection{Methodology}

Due to the lack of information on the subject of 'sensory gardens', the limitations of time for the research and the difficulties surrounding communication between the researcher and the students with speech, language and communication difficulties, two methods were thought to be the most appropriate

Table 1: Summary of the data collection at the case study site

\begin{tabular}{|c|c|c|}
\hline METHOD & RESPONDENT & OBJECTIVES \\
\hline $\begin{array}{l}\text { Interview with the landscape } \\
\text { architects: } \\
\text { B) At the place of their choice. } \\
\text { i) During a walk-through in the } \\
\text { garden. }\end{array}$ & $\begin{array}{l}\text { Landscape } \\
\text { architect }(n=1)\end{array}$ & $\begin{array}{l}\text { To investigate the design process and } \\
\text { landscape architects } \\
\text { intention; To allow subsequent assessment of } \\
\text { whether users yt se } \\
\text { the space and features in the way they are } \\
\text { meant to be. }\end{array}$ \\
\hline \multicolumn{3}{|c|}{$\square$} \\
\hline METHOD & RESPONDENTS & OBJECTIVES \\
\hline $\begin{array}{l}\text { Interview with the teachers and } \\
\text { 2. therapists. }\end{array}$ & $\begin{array}{l}\text { Teachers }(n=6) \\
\text { Therapists }(n=3)\end{array}$ & $\begin{array}{l}\text { To enquire about their experience and benefts } \\
\text { in having the } \\
\text { sensory garden; To assess the garden } \\
\text { features and identify any } \\
\text { groblems in the garden. }\end{array}$ \\
\hline \multicolumn{3}{|c|}{$\square$} \\
\hline METHOD & RESPONDENTS & OBJECTIVES \\
\hline $\begin{array}{l}\text { Interview with the students with } \\
\text { 3. special } \\
\text { educational needs. }\end{array}$ & Students $(n=6)$ & $\begin{array}{l}\text { To understand how students behave in the } \\
\text { sensory garden thus } \\
\text { providing information that observeton alone } \\
\text { cannot provide; To } \\
\text { get information first hand from the students } \\
\text { and to obtain their } \\
\text { gun responses. }\end{array}$ \\
\hline \multicolumn{3}{|c|}{ 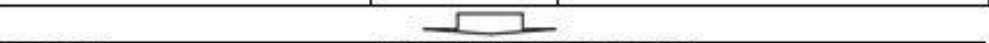 } \\
\hline METHOD & RESPONDENTS & OBJECTIVES \\
\hline $\begin{array}{l}\text { Observation and behavioural. } \\
\text { 4. mapping. }\end{array}$ & $\begin{array}{l}\text { All users of the } \\
\text { case-study } \\
\text { sensory } \\
\text { garden }\end{array}$ & $\begin{array}{l}\text { To understand how users behave and take } \\
\text { advantage of } \\
\text { affordances in space; To catecoise all the } \\
\text { different types of use } \\
\text { (bebaviout). }\end{array}$ \\
\hline
\end{tabular}


: Interview/Walk-through interview - This method was used when gathering information from the landscape architects, teachers, therapists and a selection of students with special educational needs. Observation and behaviour mapping - This method was used when collecting data of the users using the sensory gardens, particularly students with special educational needs, and when the researcher found that it was difficult to get first-hand information from those who were interviewed (see Table 1). Affordance theory was used in conjunction with these methods, in order to find out which zones were utilised in the sensory garden by the users and what the frequency of this use was.

After the interviews with the landscape architects, teachers, therapists and students had been conducted, observation and behaviour mapping of on-site activities were undertaken. This data gathering was conducted in May (spring) and July (summer), for seven days in each month. This time of year had possibly the best outdoor conditions and the period of observation was chosen to ensure that the daily variations in behaviour could be observed. The data was then recorded continuously from $8.30 \mathrm{am}$ to $3.30 \mathrm{pm}$ on weekdays, during the opening hours of the school, during the term, for thirteen separate thirty-minute periods and on different days. While undertaking the behaviour mapping, observation notes were written to provide a view of the users' additional activities and 85 potential affordances in the sensory garden. A few significant occurrences were used as anecdotal evidence to help interpret the results. Selections of photographs ${ }^{2}$ were also integrated to assist these occurrences. Behaviour mapping data later were keyed-in and analysed using Statistical Package for Social Science (SPSS).

\subsection{Results And Discussions}

What and how did the individual features of the sensory garden, as engaged with by the users, contributed to their behaviour? From the landscape architect's design, sensory garden of the Lyndale Special School was divided into 4 zones with 27 individual features (see Images 1, 2, 3 and 4). These settings afforded the students the chance to encounter some familiar features, such as the apple trees and unfamiliar features, such as the tadpoles, which the users found to be unusual in their pond. Both of these examples illustrate that the students respond differently when they encounter familiar or unfamiliar features. The individual features also afforded the students the opportunity to interact with their peers, teachers and therapists. Among social skills recorded include talking about the scented plants and herbs, singing, laughing, cheering, communicating (including via sign language), reading and counting. As such, students' use of the sensory garden appeared to offer students a stimulating experience, as well as influence their behaviour and development in terms of social relationships.

Photographs were taken by the researcher in the sensory gardens but none include shots of the users due to the school policy. 
Hussein, H., / Asian Journal of Environmen-Behaviour Studies, ajE-Bs, 2(4) Jul /Sep 2017 (p.95-108)

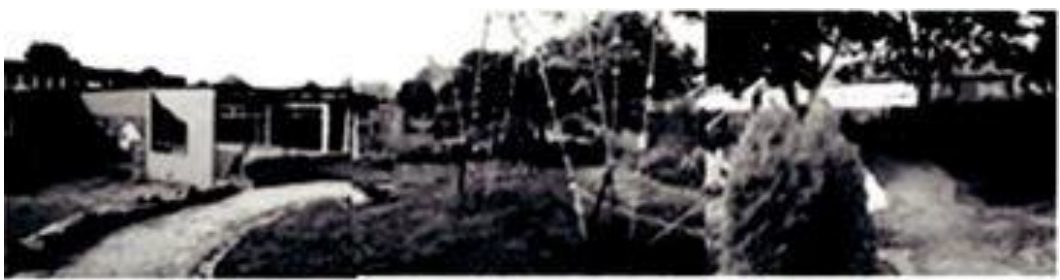

Image 1: Rainbow Walk

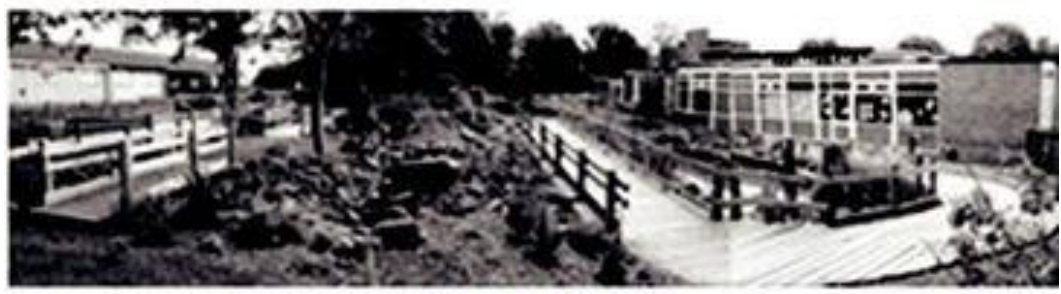

Image 2: Water Garden

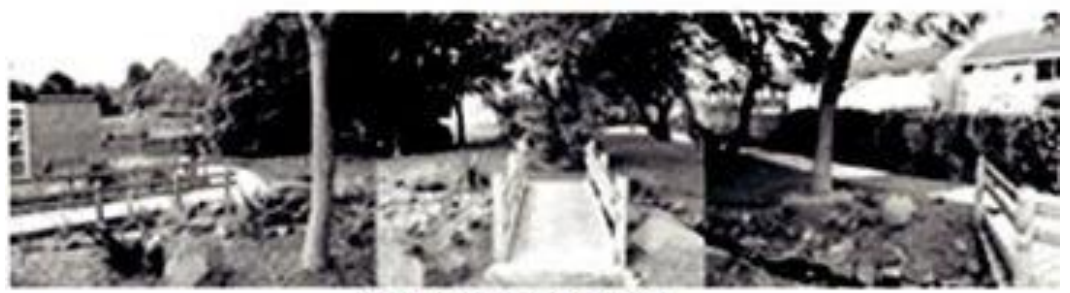

Image 3: Green Space

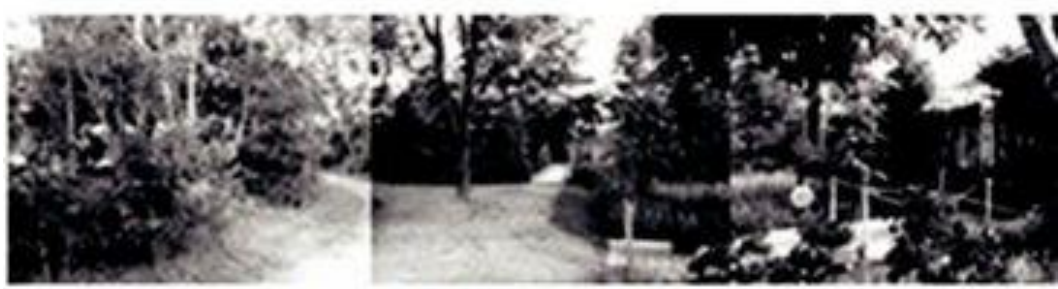

Image 4: Woodland Garden

Source: (Author, 2009) 
Table 2: Matrix of the actualised affordances in relation to the landscape design categories, the number ofusers and the total time spent per user, utilising their sensory stimulation, physical and social skills throughout all the zonesin the case-study sensory garden (Lyndale Special School in Liverpool, United Kingdom)

\begin{tabular}{|c|c|c|c|c|c|c|c|c|c|c|c|}
\hline \multirow{3}{*}{$\begin{array}{l}\text { Funcions } \\
\text { zene } \\
\text { Teist ores }\end{array}$} & \multirow{3}{*}{$\begin{array}{l}\text { Lande } \\
\text { SBISORY } \\
\text { STL } \\
\text { PHYSCL } \\
\text { ond SOCHL } \\
\text { SKLLS }\end{array}$} & \multicolumn{10}{|c|}{ 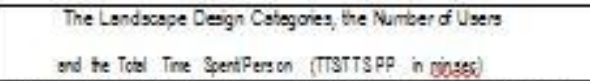 } \\
\hline & & \multirow[t]{2}{*}{ Sot } & \multicolumn{2}{|c|}{ No of Users } & \multicolumn{2}{|c|}{ TTSTTSP } & \multirow[t]{2}{*}{ Hand } & \multicolumn{2}{|c|}{ No of Users } & \multicolumn{2}{|c|}{ TTSTTSOP } \\
\hline & & & 856 & Sad & $8+6$ & sad & & $8 * 2$ & Shod & 88 & Shud \\
\hline $\begin{array}{l}\text { Fasinbou } \\
\text { Wisk (767sq } \\
\text { ostivit) }\end{array}$ & 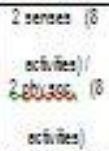 & 7 & 22 & 21 & $\begin{array}{l}57.0 \\
128\end{array}$ & $\begin{array}{l}51.30 \\
2.44\end{array}$ & 15 & 57 & 61 & $\frac{22130}{4.66}$ & $\begin{array}{l}235.30 \\
14.26\end{array}$ \\
\hline 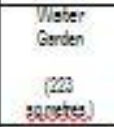 & 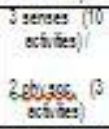 & 9 & 28 & 43 & $\begin{array}{l}48.0 \\
/ 1.71\end{array}$ & $\begin{array}{l}85.30 \\
2.38\end{array}$ & 11 & 13 & 41 & $\begin{array}{l}1630 \\
125\end{array}$ & $\begin{array}{l}51.30 \\
1125\end{array}$ \\
\hline $\begin{array}{c}\text { Green Space } \\
\text { (237 } \\
\text { seretes) }\end{array}$ & 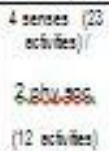 & 41 & 91 & 87 & $\begin{array}{l}9430 \\
1207\end{array}$ & $\begin{array}{l}83.0 \\
11.35\end{array}$ & 49 & 71 & 109 & $\begin{array}{l}15530 \\
3.15\end{array}$ & $\begin{array}{l}3500 \\
13.21\end{array}$ \\
\hline $\begin{array}{l}\text { Woodind } \\
\text { Gerden (665 } \\
\text { arostes) }\end{array}$ & 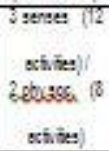 & 20 & 18 & 23 & $\begin{array}{l}9.30 \\
1.52\end{array}$ & $\begin{array}{l}13.30 \\
2.58\end{array}$ & 29 & 154 & 170 & $\begin{array}{l}2890 \\
028\end{array}$ & $\begin{array}{l}3610 \\
12.12\end{array}$ \\
\hline
\end{tabular}

\begin{tabular}{|c|c|c|c|c|c|c|}
\hline \multirow{3}{*}{$\begin{array}{l}\text { Funcional and } \\
\text { Ted ata }\end{array}$} & Lifurde & \multicolumn{5}{|c|}{$\begin{array}{l}\text { The Landscape Desgn Cokgonea, the Number } \\
\text { of Users and the Total Time Spentiferson (TTS } \\
\text { TrSp? in (uoseg) }\end{array}$} \\
\hline & \multirow{2}{*}{$\begin{array}{l}\text { SEVBORY ST } \\
\text { PHISICL and } 900 \mathrm{~L} \\
\text { SKLLS }\end{array}$} & \multirow[t]{2}{*}{ boudE } & \multicolumn{2}{|c|}{ No of Usera } & \multicolumn{2}{|c|}{$\begin{array}{l}T S \\
T T S P P\end{array}$} \\
\hline & & & 85 & Shud & $8 \%$ & Shod \\
\hline $\begin{array}{l}\text { Rainbow Wok } \\
\text { 067:qneires) }\end{array}$ & 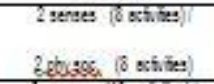 & 0 & 0 & 0 & 0 & 0 \\
\hline 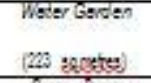 & 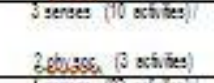 & 0 & 0 & 0 & 0 & 0 \\
\hline 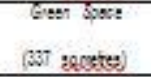 & 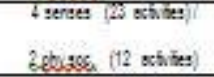 & 1 & 1 & 0 & 120 & 0 \\
\hline $\begin{array}{l}\text { Woodlend Gesden } \\
\text { (656 actes) }\end{array}$ & 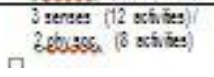 & 0 & 0 & 0 & 0 & 0 \\
\hline
\end{tabular}

Source: (Author, 2009) 
Analysis of the users and the total amount of time spent per user engaging with the individual features were divided into three categories:

Soft Landscape, Hard Landscape and Landscape Furniture. From here, a matrix of the actualised affordances in relation to the landscape design categories, the number of users and the median time spent per user was produced, according to the zones in the sensory garden. These actualised affordances were then put into three categories: Sensory stimulation (touch, taste, smell, hearing, sight); physical (mobility) and social skills (speech and communication) in a matrix form (see Table 2). These categories were produced from a combination of the taxonomy of environmental qualities by Heft (1988, $1999)$ and Kytta $(2002,2003)$ and drawing on this research experience, especially when dealing with students with special educational needs. The results showed that:

1. Rainbow Walk had recorded the highest median time spent there per user as the teachers utilised this zone as their outdoor classroom for speech therapy. However, fewer users were recorded due to poor access from the main building and from the other garden zones.

2. Water Garden recorded the least frequency of sensory affordances and the lowest median time spend per user, compared to the rest of the zones, because the sensory experiences offered there were limited.

3. The richness and functionality of features, located along an accessible and continuous pathway at the Green Space afforded users to engage with the features, thus they will spend a longer time in this zone where, sensory experience were emphasised. Here, a high quality affordance experience would encourage users to stop, engage with the various features and perhaps repeat the activity.

\subsection{Conclusions}

It is clear that the number of individual features, the number of activities undertaken and the time spent engaged in this activity by the users is not dependent on the total area of the zone, nor did it relate to the median time spent there per user, but rather on what enabled the usage was the functioning of the individual features and access to them. Good pathway design and planning that connect school buildings to the sensory garden, as well as having the ability to move around the garden, promote educational development and social skills. This finding illustrates that users, especially students, enjoyhaving a functional ..... and a variety of individual features positioned, bordering on an accessible and continuous pathway. Thus a higher number of users and a longer time spent have been recorded in relation to these design qualities. The concept of affordance and the essential qualities of a children's natural environment have been described by Sebba as follows: 'Children judge the natural setting not by its aesthetics but by how they interact with the environment' 
(Sebba, 1991, quoted in White and Stoecklin, 1998). It is clear that students with special needs do not appear to care about the aesthetics of a garden as they use the features the way they want to use them (as long as there is access to the features). Landscape architects think that aesthetic value should be the key goal but 'sensory value' is the crucial design aspect, given that users are engaged with the features, and are involved with greater use of their senses than just the visual and appreciation of the aesthetics. What the site or features look like visually is much less important than how it feels, sounds, smells and tastes, as users, who get access to the features are very important. In conclusion, it is a combination of soft, hard landscape and landscape furniture placed adjacent to a continuous primary pathway that offers easy access to the functional individual features, and this in return has recorded the highest preferences. This finding echoes the research undertaken by Moore and Cosco (2007) on inclusive parks, which showthat a highly positive feature among the users is a wide pathway that gives access to the facilities that are readily accessible. It is the layout of the pathway, therefore, that enables user behaviour and use of zone rather than users seeking out corners which have particular features. This is significant new knowledge, from a design point of view, indicating that pathway layout is more important than the particular design of individual features, as long as the pathways are accessible.

\section{Acknowledgements}

The researcher wishes to thank her supervisors, Prof. Catharine Ward Thompson and Prof. Peter Aspinall of the Edinburgh College of Art; and Jane Stoneham of the Sensory Trust. Special thanks to Women Association, for funding and making this research achievable and lastly, all respondents, for their participation in this study.

\section{References}

Best, A.B. (1992) Teaching children with visual impairments. Milton Keynes: Open University Press.

Building Bulletin 77 (1992) Designing for pupils with special educational needs: Special schools. Dept. for Education, London: HMSO.

Chawla, L. and Heft, H. (2002) Children's competence and the ecology of communities: A functional approach to the evaluation of participation. Journal of environmental psychology, 22.

Clark, C. and Uzzel, D.L. (2002) The affordances of the home, neighbourhood, school and town centre for adolescents. Journal of environmental psychology, 22.

Cosco, NG.. (2006) Motivation to move: Physical activity affordances in preschool play areas. Unpublished Doctorial, Edin. College of Art. 
Cosco, N.G. (2007) Developing evidence-based design. In Thompson, C.W. and Travlou, P. (eds.) Open space: People space. London: Taylor \& Francis.

Farrer, N. (2008) Golden moments by Tim Coulthard. Landscape Design: Journal of Landscape Institute, No. 53 , August 2008.

Frank, A. (1996) Learning curves. Landscape design: Journal of Landscape Institute, No. 249, April 1996.

Gibson, J.J. (1979/1986) The ecological approach to visual perception. New Jersey: Lawrence Erlbaum Associates.

Gibson, E. And Pick, A. (2000) An ecological approach to perceptual learning and development. New York: Oxford University Press.

Glenn, S., Cunningham, C., and Sorrock, A. (1996) Social interaction in multi sensory environments. In Bozic, N. And Murdoch, H. (eds.)

Heft, H. (1988) Affordances of children's environments: A functional approach to environmental description. Children's environments quarterly, 5 (3).

Heft, H. (1999) Affordances of children's environments: A functional approach to environmental description. In Nasar, J.L and Preiser, W.F.E. (eds.)Directions in person - Environmental research and practice. Aldershot: Ashgate.

Heft, H. (2001) Perceiver-environmental relations. In Gibson, et al. (eds.) Ecological psychology in context. New Jersey: Laurence Erlbaum.

Kytta, M. (2002) Affordances of children's environments in the context of cities, small towns, suburbs and rural villages in Finland and Belarus. Journal of environmental psychology, 22 (1).

Kytta, M. (2003) Children in outdoor contexts: Affordances and independent mobility in the assessment of environment child friendliness. Unpublished Doctorial, Helsinki University of Technology.

Lambe, L. (1995) Gardening: A multisensory experience. In J. Hogg and J.Cavet (eds.) Making leisure provision for people with profound and multiple learning disabilities. London: Chapman and Hall.

Special Educational Needs Code of Practise (2001). London: Department for Education and Skills, p.85, para.7.52

Lucas, B. (1996) A feast for the senses. Landscape design: Journal of Landscape Institute, No. 249, April 1996.

Maller, C. and Townsend, M. (2005/2006) Children's mental health and wellbeing and hands-on contact with nature. International Journal of Learning, 12(4).

Malone, K. and Tranter, Paul L. (2003) School grounds as sites for learning: Making the most of environmental opportunities. Environmental Education Research, 9 (3), August 2003.

McLinden, M. and McCall, S. (2002) Learning through touch: Supporting children with visual impairment and additional difficulties. London: David Fulton Publishers.

Moore, Robin C. (1999) Healing gardens for children. In Cooper Marcus, C. and Barnes, M. (eds.) Healing gardens: Therapeutic benefits and design recommendations. New York: John Wiley and Sons, Inc. 
Moore, R.C. and Cosco, N.G. (2007) What makes a park inclusive and universally designed? A multi-method approach. In Thompson, C.W. and Travlou, P. (eds.) Open space: People space. London: Taylor \& Francis.

Mount, H. and Cavet, J. (1995) Multi-sensory environments: An exploration of their potential for young people with profound and multiple learning difficulties. British Journal of Special Education, 22 (2), June.

O'Connell, J. and Spurgeon, T. (1996) Gardens for all. Landscape design: Journal of Landscape Institute, No. 249, April 1996.

Pagliano, P.J. (1998) The multi sensory environment: An open-minded space.

British Journal of Visual Impairment, 16 (3), September.

Pagliano, P.J. (1999) Multi-sensory environment. London: David Fulton Publishers.

Rohde, C.L.E. and Kendle, A.D. (1994) Human well-being, natural landscapes and wildlife in urban areas. Peterborough: English Nature.

Rowson, N.J. (1985) Landscape design for disabled people in public open space. Bath: University of Bath.

Sebba, R. (1991) The landscape of childhood: The reflection of childhood's environment in adult memories and in children's attitudes. Environment and behaviour, volume 23, number 4, July.

Sensory Trust http://www.sensorytrust.org.uk (Assessed Sept 2010) Shoemaker, C.A (2002) Interaction by Design: Bringing people and plants together for health and well-being. An international symposium. Ames: lowa State Press.

Stadele, Niki D. And Malaney, Lisa A. (2001) The effects of a multisensory environment on negative behaviour and functional performance on individuals with autism. Journal of undergraduate research. University of Winsconsin-La Crosse.

Stoneham, J. (1996) Grounds for sharing: A guide to developing special school sites. Winchester: Learning through Landscapes.

Stoneham, J. (1997) Health benefit. Landscape design: Journal of Landscape Institute, No 249, February 1997.

Titman, W. (1994) Special places, special people: The hidden curriculum of school ground. Cambridge: learning through landscapes/World Wide Fund for Nature UK.

White, R. and Stoecklin, V. (1998) Children's outdoor play and learning environments: Returning to nature. Early childhood news, March/April. www.whitehutchinson.com/children/articles/outdoor.shtml (Assessed Sept 2010) 